

\title{
ATTENDING UNIVERSITY COURSE AND ISLAMIC BOARDING SCHOOL: THE CASE OF PAI STUDENTS OF IAIN SALATIGA (Study of Motivation and Implications for Adversity Quotient)
}

\author{
Titik Isniatus Sholikhah1, Miftahuddin² \\ 1,2 IAIN Salatiga, Salatiga, Indonesia \\ Email: 1titik13isniatus@gmail.com, 르iftahuddin@iainsalatiga.ac.id
}

DOI : 10.30829/tar.v26i2.476

Accepted: August 10th, 2019. Approved: December 18th, 2019. Published: December 25th, 2019

\begin{abstract}
The purpose of this research is to find out the motivations of PAI (Islamic Education Department) students at IAIN Salatiga to choose to attend lecture and nyambi nyantri (attending Islamic boarding school course) and to reveal their implications for adversity quotient. This study implemented a phenomenological approach and data were obtained through interviews, observations, and documentation. The results of this study indicated that, the motivations of PAI students in IAIN Salatiga choose to nyantri nyambi lectures namely to fill their free time outside of lecture hours, to study religion more deeply, to continue their Islamic boarding school study, to consider the Islamic boarding school to be in line with the study program taken, to get a mandate from Kyai (religious authorities preferred by Javanese community) to study while mondok (living in Islamic boarding school), and their parents do not allow them to continue their study to college if they live in homestay. While the implications for the adversity quotient of PAI students of IAIN (State Islamic Institution) Salatiga are to have great aspirations, shown by the desire to graduate as soon as possible with a cum laude GPA, continuing their study to master degree, be able to read and master kitab kuning (the traditional Islamic manuscript); be able to face difficulties, demonstrated by being able to go through difficult times of adaptation, be able to overcome economic difficulties; having great self-confidence which is shown by interpreting difficulties as encouragement in achieving goals.
\end{abstract}

Keywords: Adversity quotient, motivation, studying while nyantri 


\section{INTRODUCTION}

Historical reality shows that pesantren (Islamic boarding school) until now still remain an alternative education in Indonesian society. Although considered as a traditional institution, pesantren has been able to create new vehicles for the development of Muslim civilization and society in general. It can encourage people to study in boarding schools with joy without coercion. In its development, pesantren education not only plays a role in the field of religion, but also in the field of moral revolution and social change for the benefit of the people (Takdir, 2018: 13-14). Hasbi Indra (2017: 74) also said:

"Pesantren in the future should give knowledge to santri dealt with broader perspectives in Islamic knowledge, as well as in science and technology, economic, and also give attention to santri about entrepeneurship to enhance their skill of life and then could compete with others in the world".

The heterogeneity of IAIN Salatiga students covers various aspects, such as economics, school origin, religious culture, culture, and their intelligence level. Therefore, it is not surprising that their choices vary both in the choice of study programs and places to stay during their studies. Some of them commute, live with family, live in homestay, and some others prefer to live in Islamic boarding schools. For those who choose to live in Islamic boarding schools or what the writer calls a student of Nyambi Nyantri, they certainly have their own motivation considering that the choice is a personal choice.

Based on random observations and interviews, some students chose Nyantri Nyambi because of economic problems. They believe that living in Islamic boarding school is more economical, rather than living in homestay. Some others choose to stay in Islamic boarding school because of scientific reasons, namely deepening religious knowledge and there are still many other possible interesting motives for further study. The writer deliberately chose motivation as the object of study by considering that not all students are willing and able to live in a pesantren. The volume of activities and obligations in Islamic boarding school is tight, in addition their duties and obligations relating to their studies on campus. Besides, the age of the students from a psychological perspective, they are generally still in their teenage who are emotionally unstable and religiously ambivalent (back and forth).

Therefore, a deeper study of the psychological reasons why some students choose to live in a pesantren is very important. Another assumption is that pesantren is the second campus for students who live in it which raises the assumption that the long process 
Titik Isniatus Sholikhah, Miftahuddin / JURNAL TARBIYAH 26 (2) (2019) 205-220

undertaken by students during in the pesantren and campus certainly has many demands and responsibilities, while also facing various challenges that encourage the formation of adversity intelligence to find solutions in order to achieve life plans and ideals. Therefore, how is the adversity quotient formed by college students who are nyambi nyantri in the current millennial generation?

\section{OBJECTIVE OF THE STUDY}

The purpose of this study is to find out the motivations that encourage PAI students in IAIN Salatiga to choose to attend lecture and nyambi nyantri, and to show the implications of attending lecture and nyambi nyantri for PAI students in IAIN Salatiga on adversity quotient.

\section{LITERATURE REVIEW}

Among the articles that have almost the same topic with research conducted by previous researchers are the first, the article by Ermiza (2017: 18-191) entitled " Faktorfaktor yang Berhubungan dengan Motivasi Belajar Mahasiswa Semester VI di Program Studi DIII Kebidanan STIKes Fort De Kock Bukittinggi Tahun 2013". The second is Sudarman's article (2012: 36-40) with the title " Adversity Quotient: Pembangkit Motivasi Siswa dalam Belajar Matematika ". The third article is article by Fathimah Munawaroh (2018: 46-64), entitled "Contribution of Moral Sufism Learning to Adversity Quotient ". Fourth, the article by Shalihah, et al (2018: 24-33), entitled "The Relationship Between Adversity Quotient and Career Adaptability of Internship Nursing Students ". However, the articles that discuss adversity behavior that is formed as an implication of attending course and nyambi nyantri do not yet exist. So, the researchers tried to do a study that focuses on how adversity behavior is formed PAI students in IAIN Salatiga as the implication of attending course and nyambi nyantri in the long process of taking education with various motivations that encourage it.

\section{MOTIVATION THEORIES}

As in the Dictionary of Psychology, the word motive means "The conscious reason which the individual gives for his behavior" (Chaplin, 1971: 303), including the forms of social motivation such as "achievement needs and affiliation needs" (Colman, 2009: 480). It is in line with N.S. Dister Ofm (1988: 71) who defines motivation as a psychological cause which is the source of purpose for one's actions. While Haque, et al 
Titik Isniatus Sholikhah, Miftahuddin / JURNAL TARBIYAH 26 (2) (2019) 205-220

(2014: 62) stated "Motivation is a way of creating high levels of enthusiasm to reach organizational goals, and this situation is accommodated by satisfying some individual needs". It means that motivation is a way to create a high level of enthusiasm to achieve goals and this situation is met by satisfying some individual needs.

According to Woodworth cited in E. Koeswara (1989: 67) all behavior is motivated. Without encouragement there will be no power that moves and directs the mechanism of action. The existence of motivation can stimulate a person's behavior to meet their needs or desires. In general, there are two types of motivation, intrinsic and extrinsic motivation. Intrinsic motivation is behavior that is driven by internal factors, for example personal interest and comfort. While extrinsic motivation is behavior that is driven by external factors (Koh, 2012: 89). The source of intrinsic motivation comes from needs, while extrinsic motivation is received from the goal (Petri and John M. Govern, 2013: 8). Personal needs will encourage someone to take action because everyone always wishes that their needs can be met.

A student chooses to attend course and nyambi nyantri, one of the implications is the adversity quotient. Adversity quotient itself is part of religious attitudes, because every religion teaches toughness in the face of difficulties which is according to RH. Thouless in Djami'atul Islamiyah (2013: 22-23) is influenced by four things: the first, social factors. This factor includes all social influences in the development of religious attitudes, such as teachings, parents, traditions, and the opinion of the surrounding environment. The second is the experience factor. Thouless divides this experience into 3 types namely natural experience, moral experience, and affective experience. Natural experiences, for example, are feelings of beauty, harmony and virtue in the world. While moral experience is an experience that is more internal to each individual in the form of a conflict between tendencies of their behavior with a system of conflicting rules. Affective experience is intended as an inner emotional experience that is closely related to God or other objects of religious attitudes called religious experiences. The third is the need factor. Thouless exemplifies several human needs that influence religious behavior, the need for security, the need for love, the need for self-esteem, and the needs that result from inevitable death. The fourth is the thinking factor. Humans are creatures that can think. One of the results of his thought process is that it can help him to determine which beliefs he receives or rejects. Therefore, all human behaviors are always influenced by several factors as stated above. 


\section{ADVERSITY QUOTIENT}

Webster's Ninth New Collegiate Dictionary defines the word adverse as "acting against or in a contrary direction"), while adversity refers to conditions of suffering, poverty, or misery (Dohrenwend (ed), 1998: 4-5). Adversity Quotient (AQ) is the ability or intelligence of a person to be able to survive the difficulties and be able to overcome life's challenges. Someone who has adversity intelligence will be able to face obstacles that come in the way of achieving goals (Fauziah, 2014: 79). Stoltz (2005: 8-9) states that the success of one's work and life is determined by the intelligence of adversity, where adversity quotient can show: 1) How far a person is able to survive facing difficulties and the ability to overcome them; 2) Who will be able to overcome difficulties and who will be destroyed; 3) Who will exceed expectations of their performance and potential and who will fail; and 4) Who will surrender and who will survive.

Stoltz (2005: 18-20) divides the adversity quotient into three categories: 1) Quitters, they are people who choose to leave, to avoid obligations, to withdraw, and to stop. They cover the drive to fight; 2) Campers, they struggle not too far, because they are bored to end their struggle and find a comfortable place to hide from hostile situations; 3) Climbers is someone who always thinks about the possibilities, and never let everything get in the way of his struggle. Regardless of profit or loss, they continue to struggle. Each of these categories depends on how the individual efforts in struggling and overcoming the problems faced.

According to Stoltz in Khusna et al (2017: 19-20), adversity intelligence has four dimensions commonly abbreviated as CO2RE, namely: (1) Control, Control is the ability of individuals to control the problems faced, be able to survive facing difficulties, remain firm in their intentions, and be agile in finding a solution to the problem. (2) Origin and Ownership, Origin and ownership are the ability possessed by someone to solve a problem, assume the source of difficulties comes from other people or from outside and put themselves in their proper place. Ownership is a dimension that reflects responsibility, recognizing the consequences of an action, whatever the cause. (3) Reach, Reach is used to evaluate the extent to which difficulties faced will affect one's behavior and life. Individuals who have a high $\mathrm{R}$ score will not make their difficulties spread to other aspects of life, which can cause financial panic, be difficult to sleep, keep a distance from other people, and make bad decisions. (4) Endurance, Endurance measures how long the difficulty and the cause of the difficulty will occur. Individuals who have high $\mathrm{E}$ scores will consider the difficulties and their causes to be temporary, fleeting, and less 
Titik Isniatus Sholikhah, Miftahuddin / JURNAL TARBIYAH 26 (2) (2019) 205-220

possibility to occur again. This will increase energy, optimism, and the possibility of individuals to act.

According to Anthony et al in Fauziah (2014: 82), there are several factors that affect the ability of individuals to be able to successfully adapt even in the face of difficult circumstances, namely personality, family, and the ability to learn from experience. Each individual must have a different experience. To find out the extent of one's adversity quotient, an indicator is needed. Miarti in Munawaroh (2017: 14-15) suggests that several indicators of individuals who have high adversity quotient including being able to face difficulties, being able to pursue targets, having great ideals, being able to be heartened, being able to withstand all blemishes and scorns, having great self-confident, and ready to accept criticism from others. Therefore, a person with high adversity quotient will be able to overcome the obstacles they face.

\section{AL QURAN VERSES THAT INSPIRE ADVERSITY QUOTIENT}

1. $\mathrm{Al}$ Quran surah $\mathrm{Al}-$ Insyiroh verse 5-6

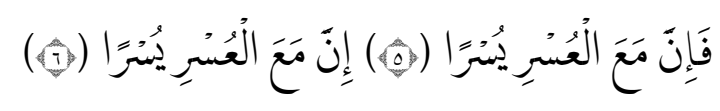

Meaning: "Verily, along with every hardship is relief. Verily, along with every hardship is relief." (Kementerian Agama RI, 2010: 596).

2. Al Qur'an surah Al-Baqarah verse 286

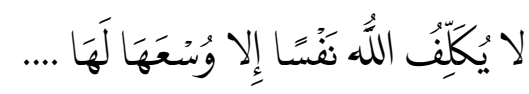

Meaning: "Allah burdens not a person beyond his scope...." (Kementerian Agama RI, 2010: 49).

The verses of the Qur'an above inspire mankind to have an adversity quotient in them. The belief in God's promises as He said is included in the things that can build strength and resilience to face the difficulties in one's life. 


\section{RESEARCH METHOD}

1. Research Types and Approaches

This research is a field research with a phenomenological approach which is trying to let the research subjects express the meaning of all their experiences naturally (Hasbiansyah, 2008: 170). This research reveals the reality of the phenomenon of attending lecture and nyambi nyantri by the PAI students of Salatiga IAIN in several Islamic boarding schools with various motivations and implications for adversity quotient.

\section{Research Subjects}

The PAI students are the most students at IAIN Salatiga. Therefore, due to limited manpower, funds, time, and mind, the researchers chose the location and informants as the subject to be studied / data sources. Determination of data sources in this study was done purposively or commonly known as purposive sampling, which is chosen with consideration and specific goals. The researchers set certain criteria that must be met by people who will be the source of the data (Afrizal, 2017: 140). The subject criteria in this study were PAI students in semester 6/8, with the assumption of researchers that at this level their personalities and experiences were more complex than freshman. The PAI students who attend lecture and nyambi nyantri are scattered in several Islamic boarding schools in Salatiga and surrounding areas. Then the researchers took two boarding schools as the site of this study. 3-5 students of santri (Islamic boarding school students) who are university students were taken from every pesantren and would continue to develop snowballing until the data was saturated.

\section{Research Site}

The site of this research was Edi Mancoro Islamic Boarding School in Tuntang, Semarang Regency and Al Falah Boarding School in Salatiga. The determination of this site took into consideration the geographical location of the Islamic Boarding School to the IAIN Salatiga Campus and the highest number of students studying at the Islamic boarding school in the area.

\section{Research Time}

This research was conducted from March to May 2019.

\section{Data Collection Methods}

(a) Interview, this method was used to get in-depth information regarding factors that encourage PAI students of IAIN Salatiga to choose nyambi nyantri at Edi Mancoro Islamic Boarding School in Tuntang and Al Falah Salatiga Islamic Boarding School, as 
Titik Isniatus Sholikhah, Miftahuddin / JURNAL TARBIYAH 26 (2) (2019) 205-220

well as the implications for the student's adversity quotient. (b) Observation, this method was used to obtain data through observations of the environmental conditions in the study and all activities related to the manifestation of students' adversity quotient. (c) Documentation. This method was used to obtain data through documents that are relevant to the research carried out such as data of students who attend lecture and nyambi nyantri, for example, the evidence of research subject documents included students who attend lecture and nyambi nyantri, boarding school profiles, and so on.

6. Data Analysis

(a) Data reduction, the amount of data collected from this research needed to be reduced, namely summarizing, choosing the main points and focusing on the important things. So the reduced data gave a sharper picture of the observations and made it easier for the researchers to find back the data obtained when needed. (b) Data Display, after reducing the data, then the data were presented in the form of narrative text. Through the presentation of these data, the data were organized, arranged in a relationship pattern, so that it would be more easily understood. Thus, researchers could master the obtained data and drew conclusions, so the collected (examined) data becomes meaningful. (c) Drawing Conclusion and verification, basically, researchers tried to find meaning from the collected data. Through data reduction, data display, and concluding, the obtained conclusions must always be verified during the study (Sugiono, 2016: 91).

In this case, the researchers tried to analyze all the collected data in the study of the phenomenon of attending lecture and nyambi nyantri by PAI students in IAIN Salatiga at Edi Mancoro Islamic Boarding School in Tuntang and Al Falah Salatiga Islamic Boarding School and its implications for adversity quotient. Furthermore, checking the validity of the data in this study used a source triangulation technique namely the researchers checked the validity of the data by comparing the data from interviews with santri who are university students and the guardians (in Islamic boarding school). In addition, it also used a triangulation technique that is comparing interview data with observational data.

\section{FINDING AND DISCUSSION}

Motivation of PAI Students of IAIN Salatiga in choosing to attend lecture and nyambi nyantri

All behaviors that appear are motivated (Koeswara, 1989: 67). Without encouragement there will be no power to stimulate one's behavior in meeting their needs 
Titik Isniatus Sholikhah, Miftahuddin / JURNAL TARBIYAH 26 (2) (2019) 205-220

and desires. As in her article, Caroline Koh describes that motivation is divided into two, namely intrinsic motivation and extrinsic motivation (Koh, 2012: 89). Motivation can increase one's enthusiasm in realizing his desires.

Among the PAI students of IAIN Salatiga who chose to attend lecture and nyambi nyantri, they were nyambi nyantri at the Edi Mancoro Islamic Boarding School in Tuntang and the Al Falah Islamic Boarding School in Salatiga. Based on the findings in the field, the motivation of most students at Edi Mancoro Tuntang Islamic Boarding School to choose to attend lecture and nyambi nyantri was classified as intrinsic motivation. Intrinsic motivation comes from needs (Petri and John M. Govern, 2013: 8). These needs encourage someone to take actions that can meet their needs. All informants in this study, namely MAM, IDW, USM, NH, and ASK chose to attend lecture and nyambi nyantri based on their own desires even though with different backgrounds and goals. MAM and IDW felt that while living in the homestay, the activities were monotonous. They need activities that fill their spare time outside of class hours and to pursue deeper religious studies. The reason for USM was to continue his studies at his Islamic boarding school during middle school and high school, while NH chose nyanmbi nyantri because it was considered to be in line with the taken study program.

So the knowledge gained from the Islamic boarding school can help even provide new insights which are not found in college. NH has good fortune; he is an awardee of bidikmisi scholarships from campus. Bidikmisi scholarships require the awardees to live in boarding schools. However, NH's motivation to nyambi nyantri comes from himself it is not because of being forced by the program. According to the researchers, there was a slightly unique motivation in this finding, the reason for being a santri and student university in the same time by ASK was trial and error. ASK observes the reality in the area where he lives, the assumption that appears living in boarding school is a scary thing, most people do not feel at home. ASK is trying to stay in and prove whether this is true or not. After trying for one week, it increased to one month and as if he felt comfortable, one semester, until now ASK is in semester 6, he is comfortable and feels at home while living in Islamic boarding school.

Considering from the religious background of the students' parents, the parents of MAM, USM, NH, and ASK were alumni of pesantren and only one informant, IDW, whose parents had never been a student in Islamic boarding school before. So, it is natural that the student's parents also support their children's motivation to attend lecture and nyambi nyantri. However, ASK's mother actually encouraged ASK to stay in homestay 
Titik Isniatus Sholikhah, Miftahuddin / JURNAL TARBIYAH 26 (2) (2019) 205-220

during the college. The mother is worried that her child, ASK, has objections to having responsibilities as students as well as santri.

In contrast to Edi Mancoro Islamic Boarding School in Tuntang, the motivation of most of the PAI students of IAIN Salatiga to choose attending lecture and nyambi nyantri at Al Falah Islamic Boarding School classified as extrinsic motivation and one student with intrinsic motivation. NAL and SNM got the mandate from their Kyai at the Islamic Boarding School during their school days, that is, if they wanted to go to college, they have to study at Islamic boarding school. So that the gained knowledge becomes more complete, namely knowledge from lectures and knowledge from pesantren. Aside from the Kyia, their parents also encourage NAL, SNM, IMS, and ESF to study at college and nyambi nyantri.

Their parents and even families do not allow them to live in homestay during college. Although SNM and IMS parents do not have a history of studying in Islamic boarding school, a religious residential environment encourages them to send their children to school in Islamic boarding school and in formal schools. While the motivation to study in college and nyambi nyantri for ZCM is classified as intrinsic motivation. ZCM wants to study in pesantren due to various reasons including wanting to continue his education in the Islamic boarding school during junior high school and senior high school, feeling comfortable with the environment, do not want to be separated from his daily routine when living in pesantren, and always be able to learn about religion even though a little.

So, based on explained above, the percentage of motivation types of PAI students choosing to attend lecture and nyambi nyantri was 60\% intrinsic motivation (MAM, USM, NH, IDW, ASK, ZCM) and 40\% extrinsic motivation (NAL, IMS, SNM, ESF).

\section{Implication of attending lecture and nyambi nyantri on adversity quotient of PAI students of IAIN Salatiga}

A student choosing to attend lecture and nyambi nyantri is one of the implications for adversity quotient. During the lengthy process of studying both on campus and in the Islamic boarding school, of course the students have goals, targets, or ideals. To achieve these goals and targets, it does not always run well. There are obstacles, difficulties, and challenges in facing life. Therefore, it requires the ability to be able to survive and overcome the difficulties encountered. This ability is what the researchers calls as the adversity quotient. MH said that Adversity quotient depends on the experience gained 
Titik Isniatus Sholikhah, Miftahuddin / JURNAL TARBIYAH 26 (2) (2019) 205-220

during the process of living with many people in one place. LTF also emphasized that Adversity quotient is very important to be built so that they can study calmly and comfortably.

The adversity quotient behavior of students who choose to attend lecture and nyambi nyantri is shown in a number of things that are consistent with the adversity quotient indicator as stated by Miarti in Munawaroh (2017: 14-15) as follows.

\section{Have great ideals}

Based on data findings in the field, all students who choose to attend lecture and nyambi nyantri at Edi Mancoro Tuntang Islamic Boarding School and Al Falah Islamic Boarding School Salatiga, they have aspirations or targets to achieve. All informants want to continue their studies after graduating S1 (undergraduate) with a cum laude GPA. In addition, MAM also wants to be the successor to his father who fought in his village and obtained a diploma to meet the conditions of looking for work. IDW wants to do service after graduating ulya. $\mathrm{NH}$ and USM also want to do community service. ZCM also wants to be able to establish Al-Qur'an madrassas in the village and master the pesantren sciences. IMS and ESF also want to graduate as soon as possible, can read kitab gundul (a traditional Islamic Arabic book without vowel in Arabic grammar), and master the book of Fiqh. In addition SNM also wants to be able to help implement character education in peseantren and serve the community after returning from the pesantren, while NAL has noble ideals that can benefit others.

\section{Able to Face Difficulties}

Looking back at the motivation of students who choose to attend lecture and nyambi nyantri with the type of extrinsic motivation that is some of the informants at $\mathrm{Al}$ Falah Islamic Boarding School Salatiga, they are experiencing hard times to adapt and carry out their responsibilities as students as well as santri. Finally, after proceeding with their various experiences, they can overcome their difficulties.

As a form of having an adversity quotient, students who study in college and nyambi nyantri are able to face difficulties. One of the challenges faced is the ability to manage time to complete college assignments and fulfill responsibilities as santri. Especially for informants who occupy positions as administrators. Their time was also drained to carry out their duties as caretakers. During the process, they were finally able to complete their responsibilities. In working on group assignments, the informants often meet group members who are not actively contributing. The informants overcame it by sharing with the active members or the last solution was to solve it himself. 
Titik Isniatus Sholikhah, Miftahuddin / JURNAL TARBIYAH 26 (2) (2019) 205-220

As the caretakers, most of the informants both at Edi Mancoro Tuntang Islamic Boarding School and Al Falah Salatiga except NAL encountered difficulties when they had to call on students to attend pesantren activities. The taken solution is to approach students who are difficult to regulate or who violate them.

In addition to the explained difficulties above, economic difficulties have also been faced by the informants. They overcome this by looking for part-time jobs that can be adjusted to their schedule in college, work, and recite in pesantren, so that their finances can be helped. Belief in Allah's promises as stated in Al Qur'an surah Al Baqarah verse 286 that Allah will not burden His servants beyond the limits of his ability, and that in every difficulty there will be facilities and help as stated in Al Qur'an surah Al Insyiroh verses 5-6 also guides the students to be ready to face challenges and difficulties. Edi Mancoro Tuntang Islamic Boarding School provides a bureau of hospitality in order to help students overcome difficulties and problems they face. $\mathrm{MH}$ also gave tausiah (Islamic speech) and advice to broaden students' insights. While Al Falah Islamic Boarding School Salatiga also provides students with book learning about morality and lectures to provide insight to students.

3. Able to achieve the target

The informants in this study, both at Edi Mancoro Tuntang Islamic Boarding School and in Al Falah Salatiga, proved to be able to pursue their targets and some of their goals during studying in college and Islamic boarding school. For example having cum laude GPA has been achieved by NAL, ZCM, ESF. In addition, the activity of reciting in pesantren, all informants can always move up to class. Even for the long term, most want to devote themselves either in pesantren or after returning to their hometown. Efforts to achieve this target were made by students who are also santri with an inner and outer effort. As the researchers observed, their efforts to learn seriously though some informants were not present when the researchers carried out learning observations (SNM, NAL, ESF, and USM) and manage the time between attending lecture and studying in Islamic boarding school. While his inner effort is to practice various riyadzoh, such as the fasting of the Sunnah of David as SNM and NAL do, and sunnah prayers like the dhuha prayer. While the other informants, Sunnah fasting in Monday-Thursday and about the habit of evening prayers, they said they could not be istiqomah or continuous. Edi Mancoro Tuntang, MH boarding school caretaker, also advised his students to fast in Monday-Thursday. Apart from that, they also hold an Istighosah every Friday night. Likewise, guiders at Al Falah Salatiga Islamic Boarding School also said that Mujahadah 
Titik Isniatus Sholikhah, Miftahuddin / JURNAL TARBIYAH 26 (2) (2019) 205-220

was held every Friday night, the certificate did not return from the Islamic Boarding School for 14 months, and gave certificate of nahun fasting, ngrowot fasting, and yaman huwa fasting as a form of santri's riyadzoh.

4. Able to withstand reproach and scorn

Most students who study at college and nyambi nyantri, they are able to withstand reproach and scorn. They are more indifferent to reproach. Just as ASK revealed "those who reproach is something that I do not prioritize". Although there are a small number of informants who still think of reproach and overcome it by approaching other students concerned.

\section{Able to Be Heartened}

This indicator is shown by students who choose to attend lecture and nyambi nyantri on an action such as giving up sandals which is ghosob (wearing something without the owner's permission). Seeing the reality, ghosob habit is a common thing in pesantren. In addition, it is also the habit of lending clothes each other, and when something is broken, they let it go.

\section{Ready to Accept Criticism of Others}

This indicator is shown by students who are also santri in their attitude of receiving criticism from friends when they have shortcomings during presentations, when in pesantren it is shown by informants who occupy positions as guiders and caretakers often receive criticism from santri members for whom they are responsible.

7. Have great confidence

After going through a long process both in college and in pesantren with various obstacles and difficulties, students who are also santri in this study became more optimistic in solving the faced problems, being able to interpret difficulties as triggers rather than as obstacles in the learning process and achieving goals.

Based on the results of the data in the field, the adversity quotient of the PAI student of IAIN Salatiga as an implication of attending lecture and nyambi nyantri was included in the category of climbers. This is shown by the success of students in achieving their ideals and targets by continuing to struggle such as being able to complete assignments both college and Islamic boarding school assignments, get cum laude GPA, always go up in class (pesantren), can overcome the faced difficulties for example difficulties as guiders in pesantren, economic difficulties, and difficult times of adaptation as students as well as students. 


\section{CONCLUSION}

Firstly, the motivations that encourage PAI students of IAIN Salatiga to choose attending lecture and nyambi nyantri include students needing activities to fill their free time outside of lecture hours, studying religion more deeply, continuing their Islamic studies during school, assuming that studying at Islamic boarding school is in line with study programs that are taken, trying to live and study in Islamic boarding school, get the mandate from Kyai in his pesantren to go to college and nyambi nyantri, and parents do not allow them to continue their study in college if they live in homestay.

Secondly, the implications of attending lecture and nyambi nyantri on the adversity quotient of the PAI students in IAIN Salatiga include: 1) Having great aspirations, demonstrated by the desire to graduate as soon as possible with cum laude GPA and continuing S2 (postgraduate) after finishing S1, wanting to devote and distribute his knowledge to the community, being able to read and master the kitab kuning, and help implement character education in pesantren; 2) being able to deal with difficulties, demonstrated by being able to go through difficult times of adaptation in carrying out responsibilities as students as well as santri, being able to manage time, being able to overcome economic difficulties by looking for part time jobs; 3) being able to pursue targets, demonstrated by obtaining cum laude GPA in college, graduating quickly in semester 8 and who are currently in the process of completing a thesis will graduate semester 9; 4) being able to withstand reproach and scorn by being indifferent and some are approaching the person concerned; 5) being able to be heartened, shown by giving up sandals that are ghosob, giving up clothes that are damaged by borrowing; 6) Ready to accept other people's criticisms, shown by accepting criticism for their shortcomings during the presentation, criticism from members of the santri to the guiders and caretakers; and 7) Having great confidence, shown by interpreting difficulties as triggers and encouragement in learning and achieving goals.

\section{SUGGESTION}

\section{For students}

(a) Add insight, knowledge, and creativity to be more able to overcome difficulties and challenges quickly. (b) More optimistic in learning and achieving targets or goals. (c) Inspiring other college student to choose attending lecture and nymbi nyantri. 
Titik Isniatus Sholikhah, Miftahuddin / JURNAL TARBIYAH 26 (2) (2019) 205-220

\section{For IAIN Salatiga}

(a) Facilitating students both inside and outside the lecture class that educates students to build adversity quotient in student selves. (b) Encouraging lecturers to always accompany students in achieving their goals.

3. For Islamic Boarding Schools

(a) Helping students to maintain and improve the built adversity quotient. (b) Adding facilities that support the building of student adversity quotient both physically and contributing knowledge.

\section{REFERENCES}

Afrizal. 2017. Metode Penelitian Kualitatif: Sebuah Upaya Mendukung Penggunaan Penelitian Kualitatif dalam Berbagai Disiplin Ilmu. Depok: PT RajaGrafindo Persada.

Chaplin, J.P. 1971. Dictionary of Psychology. New York: Dell Publishing CO.

Colman, Andrew M. 2009. A Dictionary of Psychology, Third Edition. New York: Oxford University Press.

Dohrenwend, Bruce P. (ed). 1998. Adversity, Stress, and Psychopathology. New York: Oxford University Press.

Ermiza. (2017). Faktor-faktor yang Berhubungan dengan Motivasi Belajar Mahasiswa Semester VI di Program Studi DIII Kebidanan STIKes Fort De Kock Bukittinggi Tahun 2013. Jurnal Maternity and Neonatal, Vol. 2, No. 3, 184-191.

Fauziah, Nailul. (2014). Empati, Persahabatan, dan Kecerdasan Adversitas pada Mahasiswa yang Sedang Skripsi. Jurnal Psikologi Undip, Vol. 13, No. 1, April, 7892.

Hasbiansyah, O. (2008). Pendekatan Fenomenologi: Pengantar Praktik Penelitian dalam Ilmu Sosial dan Komunikasi. Mediator, Vol. 9, No. 1, Juni, 163-180.

Haque, Mohammad Faizul, dkk. (2014). Motivational Theories-A Critical Analysis. ASA University Review, Vol. 8, Number 1, January-June, 61-68.

Indra, Hasbi. (2017). Salafiyah Curriculum at Islamic Boarding School in The Globalization Era. Tarbiya: Journal of Education in Muslim Society, Vol. 4, No. 1, 74-88.

Islamiyah, Djami'atul. 2013. Psikologi Agama: Beberapa Materi Pilihan. Salatiga: STAIN Salatiga Press. 
Titik Isniatus Sholikhah, Miftahuddin / JURNAL TARBIYAH 26 (2) (2019) 205-220

Kementerian Agama RI. 2010. Al-Qur'an Tajwid dan Terjemah Dilengkapi Asbabun Nuzul dan Hadits Sahih. Tangerang: PPPA Darul Qur'an.

Khusna, Naila dkk. (2017). Hubungan antara Adversity Quotient dan Dukungan Keluarga dengan Kematangan Karir Remaja Yatim di SMA di Surakarta. Wacana: Jurnal Psikologi, Vol. 9, No. 1, 14-27.

Koeswara, E. 1989. Motivasi: Teori dan Penelitiannya. Bandung: Angkasa.

Koh, Caroline. (2012). Moral Development and Student Motivation in Moral Education: A Singapore Study. Australian Journal of Education, Vol. 56, No. 1, 83-101.

Munawaroh, Fathimah. (2018). Contribution of Moral Sufism Learning to Adversity Quotient. Attarbiyah: Journal of Islamic Culture and Education, Vol. 3, No. 1, 4664.

Munawaroh, Fathimah. 2017. Kontribusi Pembelajaran Akhlak Tasawuf Terhadap Adversity Quotient Mahasiswa IAIN Salatiga Tahun 2017. Tesis. IAIN Salatiga.

Ofm, Nico Syukur Dister. 1988. Pengalaman dan Motivasi Beragama: Pengantar Psikologi Agama Edisi Kedua. Yogyakarta: Penerbit Kanisius.

Petri, Herbert dan John M. Govern. 2013. Motivation: Theory, Research, and Application, Sixth Edition, International Edition. USA: Wadsworth Cengange Learning.

Shalihah, Annida Nur, dkk. (2018). The Relationship Between Adversity Quotient and Career Adaptability of Internship Nursing Students. JNC, Vol. 1, No. 1, February, 24-33.

Stoltz, Paul G. 2005. Adversity Quotient: Mengubah Hambatan Menjadi Peluang. Alih Bahasa: T. Hermaya. Jakarta: Grasindo.

Sugiyono. 2016. Memahami Penelitian Kualtitatif. Bandung: CV Alvabeta.

Takdir, Mohammad. 2018. Modernisasi Kurikulum Pesantren: Konsep dan Metode Antroposentris. Yogyakarta: IRCiSoD.

Sudarman. (2012). Adversity Quotient: Pembangkit Motivasi Siswa dalam Belajar Matematika. Kreatif, Vol. 15, No. 1, 36-40 